Karol Klauza

The John Paul II Catholic University of Lublin, Poland

\title{
A Semiotic Interpretation of Pope John Paul II's Pilgrimage to Israel on 21-26 March 2000
}

\begin{abstract}
Contemporary social discourse utilizes scientific criteria to analyze events, texts and people's behaviour from the point of view of their power and impact on historical transformations. Printed and audio-visual materialregarding John Paul II's pilgrimage to the Middle East in the Great Jubilee of the Year 2000 were published and made public during his visit and shortly afterwards. In retrospect, this event allows for a well-balanced semiotic analysis focusing on the intentional selection of places visited by the Holy Father, his rhetoric used both in official and private speeches, the symbolism of his gestures and overall behaviour, especially in their religious and cultural context, as well as on the presence of signs and symbols in the whole conception of the pilgrimage project. This paper attempts to synthesize these elements which result from an earlier interdisciplinary analysis, taking into consideration the different perspectives be it historical, socio-religious (referring to three monotheist religions: Judaism, Christianity and Islam), rhetorical and aesthetic. In this case, semiotics provides a framework to analyze and justify the contribution of the mentioned pilgrimage in a broad context of a redeeming Church in the early $21^{\text {st }}$ century.
\end{abstract}

\section{Keywords}

John Paul II, Jubilee Year 2000, Judaism, Islam, dialogue of religions, semiotics of religion. 
"[T]his was where God became man, where man regained his dignity, and his vocation became a higher one." John Paul II, Rome, 29th March 2000

The phrase quoted above taken from the Papal Audience sheds light on the Jubilee Pilgrimage of John Paul to the Middle East. It has been undertaken in "the spirit of humble gratitude and hope towards the roots of our religious history, (...) as a tribute to three religious traditions, [and as] a journey through the geography of salvation history". These words were echoed by the Pontiff in Notre-Dame Institute during his meeting with the representatives of Jews, Muslims and Christians ${ }^{1}$. The scheduled program of the pilgrimage traced the history of gradual revelation of God to the Chosen People and the redemption of the Incarnate Son of God, who saved the whole world by living amongst his people ${ }^{2}$. As a result, Christ restored the dignity to each and every human being who is constantly protected by the Church established by Jesus Christ. The truth is still present in the $21^{\text {st }}$ century, and the words and events taking place during the pilgrimage recall the rich signs and symbols of life experienced by the new people of God, including Abraham, his sons and daughters and all nations. In order to read and interpret these signs, semiotics, i.e. the science of interpreting sings and symbols of civilizations, is more than useful.

Modern semiotics is particularly effective in the analysis of social discourse, especially in cultural environments such as the so-called "information society". The analysis is based on the theory of sign and symbol developed by Ferdinand de Saussure (1857-1913)3, Charles Peirce (1839-1914) ${ }^{4}$, Roland Barthes (1915-1980) ${ }^{5}$, Claude Levi-Strauss (1908-2009) ${ }^{6}$, Walter Ong, S.J.

1 K. Klauza \& M. Banaszkiewicz (eds.), Pielgrzymka Jubileuszowa Jana Pawła II na Bliski Wschód [hereafter referred to as: Pielgrzymka do źródet wiary...], Częstochowa 2000, p. 99 (transl. KK).

2 John Paul II as a Pope announced his intention to visit the Holy Land already on $24^{\text {th }}$ December 1978. However, the pilgrimage was possible only after 21 years of his pontificate, in the Jubilee Year of two millenniums of Christianity.

3 F. de Saussure, Szkice z językoznawstwa ogólnego, translation, introduction and edition by Magdalena Danielewiczowa, Warszawa 2004.

4 C. S. Peirce, The Fixation of Belief 1877. How to Make Our Ideas Clear? 1878.

5 R. Barthes, Imperium znaków, Warszawa 1999 (1 $1^{\text {st }}$ edition); 2004 ( $2^{\text {nd }}$ edition), Wydawnictwo KR, (L'empire des signes, 1970); Podstawy semiologii, transl. Anna Turczyn, Wydawnictwo Uniwersytetu Jagiellońskiego Kraków 2009.

C. Levi-Strauss, Antropologia strukturalna, 1970 ( $1^{\text {st }}$ edition), Wydawnictwo KR Warszawa 2000 ( $2^{\text {nd }}$ edition), p. 434; Warszawa 2009, Wydawnictwo Aletheia ( $3^{\text {rd }}$ edition), 
(1912-2003)7, Umberto Eco (born 1932) ${ }^{8}$ and Stuart Hall (born 1932). The latter researcher paid a particular attention to an intuitive and practical type of semiotics, which despite the rules at play, it relates the effective and opinionforming in the context of social life. The recipients of social messages, participating in the so-called semiotic guerilla warfare, based on the pluralistic interpretations of the same facts, words or declarations, are the very subject of creating this type of semiotics. This twofold semiotic interpretation, i.e. academic vs. spontaneous (social), also refers to the meaning of John Paul II's pontificate, including his pilgrimage to the Holy Land, full of clear and hidden meanings. Such analysis has developed through the years extrapolate the contemporary discourse from the conditions of the event proper.

\section{A semiotic synthesis of the Jubilee Pilgrimage}

From a historical perspective, the return of St. Peter's Successor to the geographical origins of the Catholic Church, i.e. to the Holy Land, was inaugurated in the $20^{\text {th }}$ century by the pilgrimage of Pope Paul VI ( $4^{\text {th }}-6^{\text {th }}$ January 1964), which was noticed and recorded in the cultural awareness of widespread audience worldwide. As part of the Church's aggiornamento, a revitalizing and refreshing consequence of the Second Vatican Council, Paul VI's visit to Jordan and Israel largely contributed to, inter alia, a spectacular rapprochement to the Ecumenical Patriarchate of Constantinople, represented by the $268^{\text {th }}$ Patriarch Atenagoras I (1886-1972) .

p. 454 (Anthropologie structurale 1958); Antropologia strukturalna Vol. II, Wydawnictwo KR Warszawa 2001.

W. Ong, Rhetoric, Romance, and Technology, Ithaca Cornell UP 1971; Oralność i piśmienność: słowo poddane technologii (Orality and Literacy: The Technologizing of the Word, 2002); Osoba świadomość komunikacja. Antologia, Wydawnictwo Uniwersytetu Warszawskiego, Warszawa 2010.

8 U. Eco, Pejzaż semiotyczny, Warszawa 1972; Interpretacja i nadinterpretacja (1996); Nieobecna struktura (1996); Semiologia życia codziennego (1996); Superman $w$ literaturze masowej (1996); Teoria semiotyki (2009 [1976]).

9 A Catholic-Orthodox dialogue led by Paul VI and Atenagoras I in Jerusalem, Istambul (25 $5^{\text {th }}$ July 1967) and at the Vatican resulted in the canonical abolition of excommunications from the year 1054 ( $7^{\text {th }}$ December 1965). This marked the brand new paths in achieving unity among Christians. In the spirit of the Second Vatican Council, both the Catholic Church and the Orthodox Church, represented by the Pope and the Ecumenical Patriarch Atenagoras, undertook serious efforts in order to build the community of Christian Churches. For instance, Atenagoras I met 
Paul VI's successor, commonly referred to as the "Pope from a far country", continued and developed this symbolic presence of the Head of the Catholic Churchonsame itinerary of Jesus Christ. In his pilgrimage to the Middle East in the Jubilee Year, John Paul II somehow repeated his earlier presence in the Holy Land of $1963\left(5^{\text {th }}-15^{\text {th }}\right.$ December $)$ during the visit of the "Fathers" of Second Vatican Council. After this trip, the then 43-year-old Bishop of Cracow wrote the following words in a special letter addressed to his Presbyterate: "Dear Priests, in the period of the Second Vatican Council denoting a far stage of history, which this Church has just entered, all those holy places seem to tell us the same truth: the truth of Redemption of this world. Anyone who was allowed to approach this truth through those places even closer, as he comes back to his keens, he should become a witness of God who in those places was truly present amongst the people"10.

The young Bishop, discovering a contemporary ecclesial dimension during the Council, also perceived the need for an incessant contact with tradition, whose origins reach the history of the patriarchs living in the territories nowadays belonging to Israel, Palestine, Egypt, Jordan, Syria and Iraq. Following the example of Paul VI, in the year 2000, he emphasized to the world the exceptionality of the trail of Abraham, Isaac, David and the Son of Mary of Nazareth, the Incarnate Word of the Eternal Father, in whom God assumed a human form. Primarily, a special meaning of this Jubilee Pilgrimage is a result of its symbolism, whose semantics reaches far beyond the visual boundaries of the Catholic Church. As a matter of fact, it primarily touches the people and the nations living in the land regarded as a cradle of Mediterranean civilization.

Nowadays, the symbolic message of the pilgrimage ideally fits into the history of two other monotheistic religions of the region: Judaism and Islam. Undoubtedly, it is the exceptional city of Jerusalem that is a hub of three religions of Abraham's tradition. Paradoxically, Jerusalem, in its etymology referring to peace, is a regular scene of wars and conflicts. These conflicts and acts of terror also spread to various places around the world, where the believers of those religions are present. It was already during the pontificate of John Paul II, in October 1982, when a terrorist attack on the synagogue took place in Rome near the river Tiber, not far from the Vatican. The words

Arthur Ramsey, the Primate of the Anglican Communion, thus initiating works of the common Anglican-Orthodox Commission.

${ }^{10}$ Cf. Notificationes e Curia Metropolitana Cracoviensi (1964), nos. 3-4 (transl. KK). 
of solidarity in sorrow, grief and suffering, expressed then by the Pontiff, gave rise to a cordial and solid friendly relationship with the Chief Rabbi of Rome, Elio Toaff (in office between 1951 and 2002). The visit of the Successor of St. Peter at the synagogue in Rome on $13^{\text {th }}$ April 1986 and the exchange of the kiss of peace with the head of the Jewish community of Rome was an outward, meaningful and symbolic signal of religious rapprochement and the communion in a deeply rooted Old Testament tradition.

The ecumenical feature of John Paul II's pontificate, enriched with his initiatives in the sphere of interreligious dialogue, was manifested particularly during the project referred to as the pilgrimage to the roots of faith by many historians of the Church. The Pontiff decided to visit places inextricably connected with the events of direct contact and dialogue between God and humanity. This event was to become a crucial element of the Jubilee of two millenniums of Christianity. The first stage of the pilgrimage embraced the visit of the Catholic Pope to the oldest site of monotheistic identification, which is still the Chaldean Ur (modern Tal-al-Muqayyar in Iraq), the homeland of Abraham, the Father of those who believe. The then Iraqi state government refused to give permission for the visit, hence the first stage of John Paul II's pilgrimage had only a virtual and an intentional character. The public opinion all over the world got to know the Pontiff's official texts prepared specially for this occasion during the Papal General Audiences of $16^{\text {th }}$ and $23^{\text {rd }}$ of February 2000 in the Paul VI Audience Hall at the Vatican.

The physical presence of the Holy Father in the path of the Great Jubilee pilgrimage to the origins of the Christian faith began with the Statio Orbis on $24^{\text {th }}$ till the $26^{\text {th }}$ of February in Egypt (Cairo, Mount Sinai, St. Catherine's Monastery). Together with the "Chosen People", the Holy Father symbolically returned to the surroundings where the Israelites were freed from their slavery. The mission of Moses to lead the Children of Abraham through the Red Sea and the plagues haunting their enemies were evoked in images and typological signs foreshadowing the deliverance given by the promised Messiah. The lessons learnt from the desert experience, which the Chosen People underwent before God guided them to the Promised Land, also marked the rhetoric of John Paul II. Imagery and suggestive details of this analogy were so convincing that many vaticanologists (including Luigi Accatoli and Domenico del Rio ${ }^{11}$ ) were

11 D. del Rio \& L. Accatoli, Nuovo Mose, Milano 1988, p. 173. The authors carried out a rhetoric and semantic analysis of those statements of John Paul II, which were conveyed with a raised 
inclined to treat the pontificate of John Paul II as an intentional followingin Moses' footsteps in view of his care for God's flock ${ }^{12}$.

The day before the pilgrimage inauguration, a joint document ${ }^{13}$ was issued in Israel by Ashkenazi Chief Rabbi, Yisrael Meir Lau (born 1937) ${ }^{14}$, Sephardi Chief Rabbi, Ellyahu Bakshi Doron, and the Anti-Defamation League. All the signatories listed the merits and achievements of John Paul II for a reconciliation between Jews and Catholics. The document sought to call anti-Semitism "the sin against God", to establish diplomatic relations between the Holy See and Israel in 1994, to manifest solidarity with the victims of holocaust and to reject anti-Jewish interpretation of the Holy Bible.

On the site, where Moses was granted the view of the Promised Land ${ }^{15}$, on Mount Nebo, on $20^{\text {th }}$ March 2000 John Paul II stood on the land of Jordan (Mount Nebo, Amman, Wadi-al-Kharrar - historic Bethany Beyond Jordan). Despite limited visibility, the Holy Father, just like Moses centuries ago, looked on the Valley of Jordan. There, on its horizon, he could see Bethlehem and Jerusalem. On the terrace, the Pontiff spent moments in prayer as well as contemplated on the symbolic places, which he would refer to in his message to the nations and religious communities living together in this area. The Pope's visit to the Franciscan Biblical and Archeological Institute was intended to be the foundation for these reflections.

During the Eucharistic liturgy at the Hussein International Stadium in Amman, John Paul II clearly referred to the faith of Abraham and his descendants, whom God promised this land. The God's promise was unfolding in the story of Moses, who died on Mount Nebo. The covenant sealed between

voice, or even shouted out. The passion of rhetoric involvement into the proclaimed historical and redemption events indicates the validity of the analogy of persons. "The man shouts when he sometimes has to oppose to a common opinion, feeling the burden of responsibility for himself and for others". For more on this issue, see: footnote below.

12 K. Klauza, Nowy Mojżesz, "Ethos" 3 (1990) no.1-2 (9-10), p. 412-416.

13 The full text was quoted in "New York Times". "Jerusalem Post" and Hebrew daily newspapers.

14 Born in the Polish town of Piotrków Trybunalski, son of Rabbi Moshe Chaim Lau murdered in the Treblinka extermination camp. Yisrael Meir Lau has been the Chief of Yad Vashem since 2008. His first one-hour meeting with John Paul II took place in Castel Gandolfo in 1993, which began a series of common international initiatives supported by the authority of the Pope and Chief Rabbis of contemporary Judaism.

15 Then Moses uttered a hymn prayer, a kind of blessing of generations, full of symbolic recapitulation of his mission and prophetic projection of history. Its inspired text is provided in the Book of Deuteronomy 33, 1-29. 
God and Moses, as well as the Decalogue, formed the history and customs of this part of the world. It was exactly here where the realization of the promise of Redemption in Jesus Christ was prepared. In these surroundings too was Christ recognized by the greatest prophet, John the Baptist on the banks of the river Jordan. Therefore, the afternoon Service of the Word took place at Jordan in the presence of as many as three thousand believers.While referring to the ideological assumptions of the pilgrimage, John Paul II admitted that: "after following the footsteps of Abraham and Moses, the route of the pilgrimage reached the lands where our Savior Jesus Christ lived and wandered during his earthly life"16.

In the evening of the $21^{\text {st }}$ March (Tuesday) the main part of the pilgrimage to the origins of Christian faith began. The main attraction were the sites where Jesus Christ journeyed. John Paul II stood on the Promised Land in Tel Aviv. The survey of Gallup Institute showed that 53\% of Israeli citizens expressed solidarity with this international initiative, whereas $10 \%$ were against this idea. Beyond any doubt, both political and cultural circumstances of the visit were different from the earlier pilgrimage led by Pope Paul VI. Notwithstanding the memories of a devastating holocaust, the traditions of Jewish culture remained vibrant and developing. All of this is extremely meaningful in this context. In addition, numerous immigrants from the former Soviet Union and other post-communist countries joined the Jewish kibbutzes not long before. Their mentality and worldview, formed by intensive communistic propaganda, marked a demarcation line of discourse well known to the Holy Father from the context of the communist period in Poland. Proper selection of places, gestures, words and creation of events were to determine the message at the meeting with believers representing Judaism, Islam and Christianity in the sites marking the origins of faith. Who could fail to notice the complementary presence among the different religious sanctuaries present in the Holy Land?

The following day, the $22^{\text {nd }}$ March, drew the attention of the public opinion around the world observing the Jubilee pilgrimage, to the Palestinian Autonomy. The meeting with Yasser Arafat reminded the world of the engagement of the Holy See into solving the problems of Arab population in the Holy Land, from local Christians to the followers of Islam ${ }^{17}$. Liturgy in

16 Pielgrzymka do źródet wiary..., p. 64 (transl. KK).

17 The Holy Father recalled the fact of accepting the natural right of the Palestinian nation to a peaceful and tranquil homeland in the region by the Vatican (apostolic letter Redemptionis anno 
the Manger Square had a Slavic accent as the Pope used the Polish language to quote the motto (Isaiah 9, 5) of his homily, which was conveyed in English ("For unto us a child is born, unto us a son is given: and the government shall be upon his shoulder: and his name shall be called Wonderful, Counselor, the mighty God, the everlasting Father, the Prince of Peace").

Considering the importance attributed to this place by John Paul II himself, who said that "Bethlehem is the very heart of my Jubilee Pilgrimage" 18 , the words of Isaiah conveyed publically in this place in Polish allowed for a cultural identification of Polish Jews from Israel and emigration. These words were also a cultural incorporation of the Polish language into the mosaic of languages mentioned in Acts of the Apostles during the descent of the Holy Spirit upon (Acts 2, 5-11), placing the name of God in the context of Isaiah's prophecy. There was also a break during the liturgy, which created a specific comment to the ideas expressed by the Pontiff in the homily conveyed in the Manger Square. John Paul II spontaneously decided to stop the liturgy for a while, when Muezzin's call to the prayer could be heard from the nearby mosque at noon. Instead of confrontation of religious attitudes, a common prayer of the gathered believers could echo freely in the silence of liturgy.

On the same day, another stage of the Jubilee Pilgrimage was marked by the town-symbol: Jericho. It is believed to be one of the oldest inhabited cities in the world and the oldest documented towns in the history of Salvation. The visit to Jericho was marked by evoking the baptism of Christ in the nearby river Jordan, as well as by the words of comfort and support for the Palestinian refugees in the camp of Deheisha. Apart from the reference to solidarity and engagement into improving their situation, John Paul II also brought the attention of international public opinion to the functioning of Bethlehem University, established in 1964 as a result of Pope Paul VI's visit to the Holy Land. The university, according to John Paul II, gives young people living in the refugee camp a chance for education and achieving a proper status in society. This means improving the situation of the whole generation in

of $20^{\text {th }}$ April 1984; AAS 76, 1984, p. 625-629). The Pontiff also recalled the commitment of the Holy See in the UN forum to give stable guarantees for the Palestinians, based on international law. See: Pielgrzymka do źródet wiary..., p. 74; See also: Jan Pawet II - Jubileuszowa Pielgrzymka do Ziemi Świętej: powrót do korzeni wiary i Kościoła, M. Piccirillo et al (eds.), Velar Gorle/Pallotyński Sekretariat Misyjny, Warszawa 2000, p. 203.

18 Pielgrzymka do źródet wiary..., p. 78 (transl. KK). John Paul II also acknowledged his presence in the Basilica of the Holy Sepulcher (Golgotha) and his Resurrection homily conveyed there as the peak moment of the pilgrimage. See also: Pielgrzymka do źródet wiary..., p. 139. 
economic, political, cultural and personal dimensions. Using a motif related to nearby Bethlehem, the Pontiff spontaneously modified his earlier-prepared text and pointed to a personal aspect boosting the self-esteem of his listeners by suggesting that the shepherds of Bethlehem, who first received celestial message of peace and hope, were most probably their predecessors ${ }^{19}$.

Thursday, $23^{\text {rd }}$ March, was an opportunity for a common experience of the celebration of the Eucharist in the "Upper Room", more known as the Cenacle. At the time of Jesus, the cenacle did not feature elements of gothic ornamentation. The evangelists speak of a room low in ornamentation and furnishings. It is in this background that Jesus, before his death, celebrated the Sabbath supper. He instituted the sacramental sign of real presence of His Body and Blood, the sacrament of Holy Orders and the sacrament of spiritual healing from the burden of sins committed.

For this occasion of the pilgrimage of John Paul II, the authorities made an exception and derogated from the prohibition of celebrating the Eucharist in this place. Hence, it was not surprising that in this extraordinary liturgical act, the first since the $13^{\text {th }}$ century, concelebrants representing the twelve Christian rites took part. With reference to the mystery of the Incarnation celebrated on a previous day in Bethlehem, the Christ's words "This is my Body", uttered in the Cenacle with the power of sacramental transubstantiation ${ }^{20}$, echoed in a completely different context. They were uttered with faith by the Vicar of Jesus Christ and, at the same time, the Servant of God's servants.

The symbolic character of the celebration of the Eucharist at the Cenacle reveals the power of unity.The Eucharist builds and consolidates the spiritual unity of Church. This is signified by various rites determining the identity of believers during the centuries of existence of the living organism of the Church. "For we being many, are one bread, and one body: for we are all partakers of that one bread" (1 Cor 10, 17). In this way, the Church is the coming together of the dispersed ${ }^{21}$. The reference made at the end of the Pontiff's homily to the presence of Mary and the martyrs, as well as to the expression of hope in participating at the liturgy by means of the biblical call

19 Pielgrzymka do źródel wiary..., p. 86.

20 In his homily at the Manger Square, John Paul II said: "In this Child - the Son who is given to us - we find (...) the true bread that never fails - the Eucharistic Bread foreshadowed even in the name of this town: Beth-lehem, the house of bread“" (Pielgrzymka do źródel wiary..., p. 79).

21 Pielgrzymka do źródet wiary..., p. 91. 
"Marana tha!" ("Come, Lord", cf. also: Ap 22, 17), added a special ecumenical and eschatological aspect to this exceptional event in the Cenacle.

The meeting with the Chief Rabbi of Israel at the main seat of the rabbinate at the Hechal Shlomo was also full of rich symbolic meanings. The event was a preparation for a common diplomatic and religious tribute paid at the Yad Vashem Institute, Israel's Holocaust Museum and Memorial ${ }^{22}$. Apart from recapitulating the hitherto achieved successes of Vatican-Israeli co-operation, the participants also discussed the proposal for opening the Vatican archives for research on the situation of Jews in the occupied Europe during World War II. In view of this, John Paul II said during the meeting: "We have so much in common. Together we can do many things for peace, justice, for a more human and fraternal world" 23 .

Another important feature that marks this event was an equally symbolic meeting with the representatives of Islam, Judaism and Latin Patriarchate of Jerusalem. The artistic background for this event was provided by the choir formed by representatives of these religious communities. This provided the Pontiff with an opportunity to utter words that were to be widely referred to and commented: "Religion is not, and cannot become, an excuse for violence and conflict, especially when religious, cultural and ethnic identity coincide. Religion and peace go together"24. John Paul II described the presence of Jewish, Christian and Muslim children in the choir as a "sign of hope and a challenge".

The schedule for Friday, $24^{\text {th }}$ March, referred to the Beatitudes mentioned in the Sermon on the Mount . Pope John Paul II, in the presence of hundred thousand participants at the liturgy, including young people from eighty countries, pointed to the presence of the Greek Melkite community, Christian Jews, Maronites, Syrians, Armenians, Chaldeans, as well as Muslims and Druzes. In torrential rains and biting cold, Poles too flocked to that event, indicating their presence with Polish flags and banners. The Pontiff directed his words to all those bravely battled unfavorable weather conditions and

22 The Institute, established in 1953, consists of: the Hall of Remembrance full of martyrological symbolism, the Holocaust History Museum with the archive presenting information about the victims, the Holocaust Art Museum, the synagogue and the Garden of the Righteous Among the Nations, in which more than 12 thousand trees are marked with the names of Poles. In the area surrounding the complex there is, among others, the monument of Janusz Korczak.

23 Pielgrzymka do źródet wiary..., p. 94.

24 Pielgrzymka do źródet wiary..., p. 101. 
encouraging them to discover new vocation in today's world and prepare its realization in the school of Jesus. The situational motif was in this case a clear reference to the place, where Jesus called his disciples who followed Him. The Pope finished his homily with these words: "O Lord Jesus, you have made these young people your friends: keep them for ever close to you!" The liturgy was complemented with the presence of John Paul II in the Church of the Multiplication of the Loaves and Fish at Tabgha, the Church of the Primacy of St. Peter and St. Peter's House in Capernaum.

According to the liturgical calendar, John Paul II celebrated the liturgical feast of the Annunciation on Saturday ( $25^{\text {th }}$ March) at the grotto of the Annunciation in Nazareth. The Pontiff returned to the issues pertaining to Mariology in the texts presented at the end of the whole pilgrimage, on Sunday, $26^{\text {th }}$ March. The subject of Redemption was additionally incorporated into the reflection inspired by the motif of the Annunciation scene during the prayer at the Basilica of the Agony at the Garden of Gethsemane. John Paul II emphasized that the stones, olive trees and the rock of Gethsemane were the witnesses of the mystery of Christ full of fear before his agony ${ }^{25}$. The later prayer in the Basilica of the Holy Sepulchre with the representatives of Eastern and Western Christian Churches integrated all the believers around the prayer for the unity of Church, contemplating the Incarnation and Redemption of Jesus Christ in this very special place on earth.

This is the reason why for so many centuries the Euro-American world treated Jerusalem, a City of Peace, as the navel of the earth and axis mudi, a central point of reference, a destination of pilgrimages for strengthening one's faith, an aim of crusades to preserve identity, or a site of diplomatic efforts to reconcile religious tensions and social conflicts.

The fact that, despite an enormous progress in the world, it is so difficult to achieve peace indicates that this place is a scene of clash between the history of Redemption with misterium iniquitatis, originating from sinful human choices.

Hence, standing firm in Jesus Christ (as in the appeal directed by the Pontiff to the youth at the foot of the Mount of Beatitudes), as well as cultural and religious collaboration (as in the proposals directed towards religious and political leaders), determine the semiotic message of the pilgrimage.

25 Pielgrzymka do źródet wiary..., p. 138-139. 
The agenda of the pilgrimage for Sunday $26^{\text {th }}$ of March also conveyed meaningful symbolic gestures. The first important point was the meeting with Ekrima Sabri, the Grand Mufti of Jerusalem and Palestine, followed by a tedious walk to the Wailing Wall, the last authentic fragment of the ancient Temple of Jerusalem, which has never been rebuilt after it was damaged by the Romans in $70 \mathrm{AD}^{26}$. Just like the believers of Judaism, the Pontiff placed a note in a crack of the Western (Wailing) Wall with the following prayer and message: "God of our fathers, You chose Abraham and his descendants to bring your Name to the Nations: we are deeply saddened by the behavior of those who in the course of history have caused these children of yours to suffer, and asking your forgiveness we wish to commit ourselves to genuine

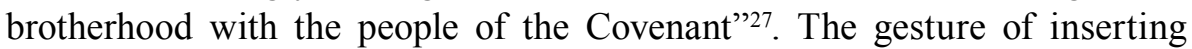
a note with a prayer, also popular in many Christian shrines, attained a special meaning of interreligious dialogue in Jerusalem owing to the figure of the Holy Father and his private engagement in the religious practice of the believers of Judaism.

The Basilica of the Holy Sepulchre became the last station of the Jubilee Pilgrimage. The motto of the farewell homily was a fragment of the Credo: "I believe in Jesus Christ (...) conceived by the power of the Holy Spirit and born of the Virgin Mary. He suffered under Pontius Pilate, was crucified, died and was buried... On the Third day he rose again" ${ }^{28}$. This text, so fundamental for the identity of all believing in Christ, expressed by the Head of Catholic Church in the place providing evidence for the constancy of apostolic tradition, possesses a multidimensional sense, that is religious, cultural, social, but also individual and personal. This is exactly as in the case of every pilgrim who visits this marvellous basilica with deep faith. At this place, as John Paul II admitted, "Resurrection (the fundament of faith, without which faith would be futile-cf. 1 Cor 15, $14-$ K. K.) is the sign that the Eternal Father is faithful to his promise and brings new life out of death: the resurrection of the body and life everlasting, guaranty of history marked with messianic gifts of peace

${ }^{26}$ It is difficult to treat a provisional object constructed during Bar-Kochba revolt as rebuilding or reconstruction of the temple. A sad remembrance of the temples damaged in $586 \mathrm{BC}, 70 \mathrm{AD}$ and after the fall of Bar-Kochba revolt is celebrated during Tisha b'Av, the $9^{\text {th }}$ day of the month Av.

27 Pielgrzymka do źródet wiary..., p. 127. The prayer was printed on an ornamentive sheet of paper with the date, Vatican stamp and signature of John Paul II. The document was later taken to the archives of Yad Vashem Memorial Institute.

28 Pielgrzymka do źródet wiary..., p. 128. 
and spiritual joy"29. The words were uttered in the light of witness to life, awareness of Christian hope and mature joy of an elderly man who gained exceptionally convincing power.

The Sunday prayer of the "Angelus Domini" ("the Angel of the Lord") gently embraced all the public addresses of John Paul II made during his visit to the Holy Land. In the editorial plan of the whole pilgrimage catechesis it can be treated as a Mariological colophon, so often used by the Holy Father in editing his doctrinal documents, like encyclicals, apostolic letters or constitutions, as well as in numerous catecheses presented during his public and private audiences. Also during this time, the teaching of the Jubilee Pilgrimage to the origins of faith finished with a beautiful and deeply theological typology of Mary and Ecclesia: "Considering Theotokos - Mother of God - now, at the end of this visit, we look at the real face of Church, shining with all her beauty, shining with "the light of knowledge of the glory of God in the face of Christ"" $(2$ Cor 4,6$)$. This typology frequently appears in the Mariology of John Paul II both in his cycle of Marian catecheses ${ }^{30}$ and his teaching scattered in other documents of the magisterium ${ }^{31}$.

The Christocentric Mariology of the "Polish Pope" grew out from his Marian devotion he learnt at home, from the pastoral appreciation of Marian shrines, from Marian motifs of art influencing his emotional sensitivity and from renewing traditional forms of Marian spirituality. Symbolic elements appeared during the discussed pilgrimage each time the Holy Father referred to the places and events connected with Mary of Nazareth.

\section{Essential elements of semiotic analysis of the Jubilee Pilgrimage}

From the semiotic point of view, the message of John Paul II's pilgrimage to the origins of faith in 2000 is connected with the following aspects:

- a conscious selection of visited sites,

- a rhetoric of official and private speeches,

29 Pielgrzymka do źródet wiary..., p. 132.

${ }^{30}$ More on this subject, $c f$. inter alia: K. Klauza, I tratti fondamentali della mariologia nelle „Catechesi mariane, in: La Vergine Maria nel magistero di Giovanni Paolo II, T. Siudy (ed.), Città del Vaticano 2007, p. 255-270.

31 See: A. Szostek \& M. Filipiak (eds.), Jan Pawet II o Matce Bożej 1978-1998. Homilie i przemówienia, Warszawa 1998. 
 \\ - a symbolism of gestures and behaviors, especially in their religious and cultural context, \\ - a formal attention drawing to the presence of signs and symbols in the global ideological concept of the pilgrimage project.}

\subsection{A conscious selection of the visited sites}

A symbolic meaning of the places of John Paul II's presence during the pilgrimage stems from the biblical story of Abraham and Moses, as well as from the evangelical chronology of redemption events of Jesus Christ. After the purely spiritual pilgrimage to Chaldean Ur, caused by the refusal of the Iraqi government, official and church events took place. They referred to the Egyptian slavery of Israelites, the emigration of the Holy Family due to Herod's persecutions and the development of the Church of Jesus Christ from the first century A. D. It was also here, where the Christian monasticism appeared, which would play an important role in the life and culture of ancient, medieval and modern civilization. The homilies and speeches of John Paul II, first Latin Pope in history in the land of St. Mark's evangelization, evoked the symbolism of this land.

Egypt, connected to the struggles of Israel and leaving slavery to freedom and sovereignty, was followed by the pilgrimage stations in Jordan and Israel, connected with the Incarnation of the Son of God (Bethlehem, Nazareth), apostolic teaching of historic Jesus (Jericho, Mount of Beatitudes, Tabgha, Capernaum) and Jerusalem stations connected with Jesus Christ's agony, death and resurrection (refugee camps for Palestinians, Cenacle, Gethsemane Garden, Golgotha, Basilica of Sepulchre). Places related to interreligious dialogue, like Hechal Shlomo, Notre-Dame Institute, Yad Vashem Memorial Institute, Wailing Wall, possess a different significance. John Paul II also visited the river Jordan twice. In the initial stage of the pilgrimage, in Wadi al-Kharrar on the Jordanian side, the Pontiff blessed and sprinkled the participants of the event with the water of Jordan. For a second time, at the West Bank of Jordan near Jericho, the Pope stopped there on the way to Bethlehem.

A special attention should be paid to the Pope's meeting with Muslims, especially with the Grand Mufti of Jerusalem, Ekrima Sa'id Sabri (in office in the period of 1994-2006). Of not less importance is his presence and participation at the concert organised by the choir consisting of the representatives of the Jewish, Muslim and Christian communities. The event 
took place only one year before the terrorist attack of Islamic fundamentalists on the World Trade Center, i.e. before the event which was to wipe out for long years a perspective of agreement and collaboration emerging after this visit. The impressive mileage of the whole pilgrimage, as well as the specificity of places reached by John Paul II in the condition characteristic for an elderly and ailing person, also shows the determination of the Holy Father to build a symbolism of presence. The significance of the symbolism of Jerusalem should be particularly stressed with reference to its semantic meaning for three major monotheistic religions of contemporary world. For Christians, it gets down to the meaning of the Cenacle, the complex of the Constantine basilica, a witness of Church's evolution during long centuries, the Mount of Olives and Gethsemane Garden, where the witnesses of mystery [Redemption - K. K.] are olive trees and the rocks, where Christ, full of fear, prayed to his Father before His Passion ${ }^{32}$. It is also a universal shrine of the Shoah at the complex of Yad Vashem Memorial Institute.

The pilgrimage path additionally embraced the capital city of Tel Aviv, Nazareth with the grotto of Annunciation, historic Jericho, Bethlehem and the refugee camps for Palestinians. There were also diplomatic lounges, institutes and camps with tents of Palestinian exiles, full of human suffering. The pilgrimage embraces the Mount of Beatitudes and traces St. Peter's presence atTabgha and Capernaum. The difficulty in getting to those places required from the Pope an exceptional humility in view of his physical strength. He was determined that the historical encounter of the realities of the Ecclesia, a Synagogue and a Mosque is necessary and possible. It can also successfully open a new phase of reconciliation, radiating from Jerusalem, a City of Peace, to all the places of religious conflicts around the world. It was his prophetic intuition along with a strenuous effort that brought to realisation such a Jubilee Pilgrimage. In this respect, the idea of a pilgrimage, so zealously realized by the Polish Pontiff, was originally the inspiration of another prophet of Jewish-Christian dialogue, Abraham Joshua Heschel (1907-1972). Heschel was a Jewish philosopher and theologian born in Warsaw, Poland ${ }^{33}$. He served as an expert or consultant

32 Pielgrzymka do źródet wiary..., p. 139.

33 Life and opinions of Heschel were thoroughly discussed in the doctoral dissertation of Rev. Waldermar Szczerbiński (Catholic University of Lublin, 2000). For more on the main theses, see: W. Szczerbiński, Abraham Joshua Heschel - odnowiona teologia proroctwa, in: Więksi i mniejsi prorocy Europy Środko-Wschodniej XX wieku, K. Klauza, S. C. Napiórkowski, K. Pek (eds.), Lublin 2003, p. 291-318. 
of Judaism during the Second Vatican Council (especially in relation to The Declaration on the Relation of the Church to Non-Christian Religions). Heschel is equally known for his friendship with Pope Paul VI. He was also close to Cardinals responsible for the "ad extra" contacts of the Church, including Cardinal Augustin Bea, S.J. (1881-1968) and Johannes Willebrans (19092006), who both exerted a serious influence on the direction of Christian-Jewish dialogue. Through these contacts, Heschel proposed "a complete elimination of the idea of mission among the Jews. (...) They managed to convince even the Pope, (...) who personally crossed out a paragraph referring to conversion and mission among the Jews. I said: I prefer to go to Auschwitz rather than to recant my faith" ${ }^{34}$. All this marks the spirit of the pilgrimage of Paul VI to the Holy Land in 1964. Years later, John Paul II joined this movement seeking ever stronger unity and community among the believers of the religionspresent there. The Polish Pope's presence in the footsteps of Abraham and Mose, as well as in following Jesus Christ on earth was another step toward the commitment in "genuine brotherhood with the People of Covenant", as he wrote in his prayer inserted into the Wall of Wailing.

\subsection{Symbolism in speeches}

In many fragments of the Pope's speeches and addresses with a symbolic meaning, special attention should be paid first to the rhetoric of formal gestures, including:

1. moments of silence - e.g. in Bethlehem after the homily, the Holy Father stopped the liturgy of the Holy Mass for a while when Muezzin's call to prayer could be heard at noon,

2. prayer and, at the same time, a form of religious communications with the world by means of the gesture of inserting a note into a crack of the Wailing Wall - the cracks become deeper and deeper every year due to the intensiveness of requests directed to God. The requests symbolically cause erosion of walls of historic division among people,

3. using Polish language in the motto of the homily in the Manger Square in Bethlehem. It pointed out to the radiation of the mystery of Incarnation to the regions distant from the Holy Land, to people speaking different languages, but returning to the source of faith, Bethlehem and Jerusalem, seeking their identity there,

${ }^{34}$ Cf. W. Szczerbiński, Abraham Joshua Heschel..., p. 317 (transl. K. K.). 
4. quoting Christian Credo in the Chapel of Sepulchre was equally significant. Focusing on Resurrection in this place had a clear symbolic meaning. It allowed for treating the motif of life after death as the answer of the Church and all Christian communions built on the foundation of this truth of faith to the desire of a modern man to live a life not determined by death. In this rhetorical motif, there is also deep significance of Christianity in protecting the dignity of humanity revealed, which human life crosses the inevitable barrier of death and gives it an eternal sense,

5. contentwise, in the rhetoric of John Paul II's speeches, there appeared a series of substitutive image-symbols or even a direct assumption of various events, things and people as symbols. The most important of them was, in chronological order, recalling a paraliturgical gesture from $18^{\text {th }}$ of January 2000 during opening the Holy Door in the Basilica of St. Paul Outside the Walls. Then the Catholic Pontiff, Bishop Amba Bishoi of the Coptic Church and the representatives of the Orthodox and Lutheran Churches carried the Book of Gospels to four sides of the world. The open door of the basilica was the symbol of common walking through the doorway symbolizing Jesus Christ (cf. Ecumenical Meeting on $25^{\text {th }}$ of February). The liturgy was completed with the sign of peace as a foretaste and announcement of the full communion among all the followers of Jesus. The Jubilee Pilgrimage of 2000 was full of similar gestures and declarations.

Mount Sinai and the nearby Red Sea also had a symbolic meaning for the Holy Father as crucial elements of the promise of liberation and fulfilling the promise in a miraculous way (See the Speech on Mount Sinai, $26^{\text {th }}$ February) ${ }^{35}$. Faithfulness to the Covenant measured by obedience to the Decalogue was a reality connecting these two places. According to the Pontiff, the sign of monasticism represented by the communions of the Incarnation and St. Catherine's Monastery at the foot of Mount Sinai indicates the way of fulfilling this faithfulness in the New Covenant. The monastery was described by the Pope as a "sing of God's wisdom and love" 36 .

The reference of the Pontiff to German Christmas Museum, opened in Rothenburg ob-der-Tauber in Bavaria in 2000, shows how a religious feast related to the birth of Jesus became a crucial part of culture and art in all

35 Pielgrzymka do źródet wiary..., p. 38-39.

36 Pielgrzymka do źródet wiary..., p. 42. 
parts of the world. This had a substantive character of the sign evoked during his homily in Bethlehem ${ }^{37}$. The Church of the Nativity in Bethlehem, which stands like a "fortress strafed in the battle of centuries", was described by John Paul II as being iconic or a true symbol of the difficult ecclesiastical history: "Christ's manger always stands in the shadow of the Cross" 38 .

While addressing the youth on the Mount of Beatitudes, the Holy Father referred to the evangelical motif of leaving the boat in order to follow the call of Jesus Christ, which is never easy - especially if we consider the uncertain that lies ahead ${ }^{39}$.

\subsection{Symbolism of gestures and behaviour, especially in their religious and cultural context}

The symbolism of gestures and behaviour, related to extra-verbal rhetoric, primarily embraced situations with a religious character, mostly interreligious and ecumenical contacts. In this case, these gestures and behaviour drew attention to the difficult practical coexistence of six Catholic communions (Latin, Melkite, Armenian, Maronite, Syrian and Chaldean), eight Orthodox communions (Greek, Armenian, Coptic, Ethiopian, Syrian, Nestorian, Russian and Romanian), three Protestant communions and one Anglican. Since the $19^{\text {th }}$ century, this coexistence has been normalized by the regulations controlled by secular authorities and customs. Hence, the common saying of the Paternoster prayer in the seat of the Greek Orthodox Patriarch Diodor I, finished with the sign of peace, carried an exceptional character. The incident in the stairs of the Golgotha shrine was an unexpected complement of this gesture. As a result of climbing steep stairs and fatigue, John Paul II swayed in a dangerous manner. Nonetheless, he was instantly assisted by a Greek-Catholic priest. This event turned into a meaningful gesture of cordiality and the symbol of collaboration of priests at the foot of the historic Golgotha ${ }^{40}$. The University of Bethlehem, established by Paul VI in 1964, also possesses its symbolism as the sign of "Church's service for the sacred matter of education ${ }^{41}$.

37 Pielgrzymka do źródel wiary..., p. 73-74.

38 Pielgrzymka do źródet wiary..., p. 80.

39 Pielgrzymka do źródet wiary..., p. 109.

40 Symbolism of places and gestures is discussed, among others, in: P. Ptasznik, Śladami Chrystusa, "Osservatore Romano" 2000, no. 5; www.opoka.org.pl/czytelnia (01.08.2014).

41 Pielgrzymka do źródet wiary..., p. 85. 


\subsection{Attention to the presence of signs and symbols of the global ideological concept of the pilgrimage project}

The most meaningful sign, analyzed semiotically by John Paul II, was Eucharist. The first part of the homily in the Cenacle, based on the quotes from the Letter to the Hebrews, clearly indicated a multidimensional significance of Transfiguration, Presence, Sacrifice, Breaking of Bread (Fractio Panis), as well as the spiritual unity of Church, built by the Sacrament of Body and Blood of Christ ${ }^{42}$.

The meeting with the Chief Rabbis of Israel in Hechal Shlomo had, according to John Paul II, a symbolic meaning in achieving a deeper understanding of the historical and theological bonds between Christianity and Judaism $^{43}$. Common declarations announced there evidenced a perspective of collaboration. In turn, in Yad Vashem Memorial Institute, the Pontiff referred to the symbolism of silence "in which to remember (...), in which to try to make some sense of the memories which come flooding back (...) because there are no words strong enough to deplore the terrible tragedy of the Shoah" ${ }^{\prime 4}$. The Papal address refers to a poetic rhetoric, drawing the pictures of "echo of the heart-rending lament of so many" men, women and children, all resulting from reaching the "point of contempt for God"

At Notre-Dame Institute, John Paul II described the engagement of children and youth representing three monotheistic religions into the musical artistic scenery of this interreligious meeting, marked by some diplomatic and situational tensions, as a "sign of hope and incentive" for peace in the region ${ }^{46}$.

A positive meaning of historical variety of Churches and Communions was summarized by John Paul II as a proof of a richness manifested by God and an inseparable heritage of the universal Church. Hence, common respect and support were needed, according to the Pope, in order to develop a Christian presence in the local communities while safeguarding their living traditions ${ }^{47}$.

John Paul II's reference to the category of "The People of the Book" or "The People of the Scripture" is ambiguous in its character. On the one hand,

42 Pielgrzymka do źródet wiary..., p. 89-91.

43 Pielgrzymka do źródet wiary..., p. 93.

${ }^{44}$ Pielgrzymka do źródet wiary..., p. 95.

45 Pielgrzymka do źródet wiary..., p. 97.

46 Pielgrzymka do źródet wiary..., p. 102.

47 Pielgrzymka do źródet wiary..., p. 122-123. 
the document inserted into a gap of the Wailing Wall historically belongs to Judaist semantics and the concept refers to the people having reverence to the Book of Torah, which actually made them "the People". An outward sign of this veneration is the annual feast of Simchat Torah, during which the last verses of The Book of Deuteronomy are recited, as well as the first verses of The Book of Genesis. The recitation is intermitted seven times with singing, cheers of joy and dance. On the other hand, in Islam the term "People of the Book" (Arab. Ahl al-Kitab) has referred to Christians, Jews and Sabians since the $9^{\text {th }}$ century, according to the statement in the Quran (Sura 5, The Table spread). In this way, the believers of those religions were distinguished from among non-muslims, as the message of The Book of Torah and The Book of Gospel had a value approximate to the Quran for Muslims, however requiring some clarification: "O People of the Scripture, there has come to you our Messenger making clear to you much of what you used to conceal of the Scripture and overlooking much" (Sura 5,15). Ambiguity and versatility of the Pontiff's formulation is part of the religious context of the Holy Land, giving it a broader interpretation depending upon the assumed paradigms.

A lavish set of symbols was incorporated into John Paul II's Mariological colophon used in his pilgrimage, i.e. in the reflections for the "Angelus" on the last day of the visit to the Holy Land. In this short text, there appeared the symbols of the Stabat Mater (Our Lady of Sorrows), the Stella Matutina (Morning Star) in the context of the Light of Resurrection and the Theotokos as a true face of the Church, shining with all Her beauty (the hidden image of the Immaculate Conception) ${ }^{48}$.

As a matter of fact, each of the above-mentioned rhetorical meanings used during the pilgrimage deserves a separate analysis. What determines the final evaluation of the ideological message of the pilgrimage through verbal and nonverbal (extra-verbal) means of discourse utilized by John Paul II is the richness of the theological symbolism with a high intensity of emotional involvement. To a considerable degree, this is an outcome of thoroughly considered and deeply experienced historical encounter of the Author of these statements in the Land of Jesus with the Lord and through the Lord with brothers in faith, and in the communion of Church in all circles of its existence mentioned in the Dogmatic Constitution on the Church (Lumen Gentium): "They are fully incorporated in the society of the Church who, possessing the Spirit of Christ

48 Pielgrzymka do źródet wiary..., p. 134-135. 
accept her entire system and all the means of salvation given to her, and are united with her as part of her visible bodily structure and through her with Christ (...)", in relation to people who "being baptized, are honoured with the name of Christian, though they do not profess the faith in its entirety or do not preserve unity of communion with the successor of Peter (...), those who have not yet received the Gospel are related in various ways to the people of God. In the first place we must recall the people to whom the testament and the promises were given and from whom Christ was born according to the flesh. [Also] Muslims, who, professing to hold the faith of Abraham, along with us adore the one and merciful God, who on the last day will judge mankind [... and finally] nor is God far distant from those who in shadows and images seek the unknown God..." (see: Pielgrzymka do źródel wiary..., p. 14-16). John Paul II's pilgrimage to the origins of faith constitutes an important milestone on the way to understand the boundaries of a Redeeming Church.

\section{Bibliography}

Barthes R., Imperium znaków, (2 ${ }^{\text {nd }}$ edition) Warszawa 2004; ( $1^{\text {st }}$ edition) 1999.

Eco U., Teoria semiotyki, transl. M. Czerwiński, Kraków 2009.

Piccirillo et al., Jan Pawet II - Jubileuszowa Pielgrzymka do Ziemi Świętej: powrót do korzeni wiary i Kościoła, Velar Gorle/Pallotyński Sekretariat Misyjny, Warszawa 2000, p. 203.

Szostek A. \& Filipiak M., Jan Pawet II o Matce Bożej 1978-1998. Homilie i przemówienia, Warszawa 1998.

Klauza K., I tratti fondamentali della mariologia nelle „, Catechesi mariane”, in: La Vergine Maria nel magistero di Giovanni Paolo II, T. Siudy (ed.), Città del Vaticano 2007, p. 255-270.

Klauza K., Nowy Mojżesz, „Ethos” 3 (1990), no. 1-2 (9-10), p. 412-416.

Peirce C. S, The Fixation of Belief, Popular Science Monthly (1877), p. 209-212.

Peirce C. S., How to Make Our Ideas Clear, Popular Science Monthly (1878), p. 212-218.

Pielgrzymka do źródet wiary... = Klauza K. \& Banaszkiewicz M., Pielgrzymka do źródet wiary. Pielgrzymka Jubileuszowa Jana Pawła II na Bliski Wschód, ["Biblioteka Niedzieli”, vol. 94], Częstochowa 2000.

Rio D. del \& Accatoli, L., Nuovo Mose, Milano 1988.

Szczerbiński W., Abraham Joshua Heschel - odnowiona teologia proroctwa, in: Więksi i mniejsi prorocy Europy Środkowo-Wschodniej XX wieku, K. Klauza, S. C. Napiórkowski, K. Pek (eds.), Lublin 2003, p. 291-318. 